\title{
Pengaruh Norma Subyektif, Kinerja Aparatur, Kejelasan Sasaran Anggaran, Prosocial Behavior Terhadap Transparansi Dan Akuntabilitas
}

\author{
Ikhwan Wadi ${ }^{1}$ \\ Fakultas Ekonomi dan Bisnis \\ Universitas Mataram, Indonesia \\ Email: ikhwanwadi58@gmail.com
}

\author{
Lalu M. Furkan² \\ Fakultas Ekonomi dan Bisnis \\ Universitas Mataram, Indonesia
}

\author{
Ahmad rifa' $i^{3}$ \\ Fakultas Ekonomi dan Bisnis \\ Universitas Mataram, Indonesia
}

\begin{abstract}
ABSTRAK
Penelitian ini bertujuan untuk mengaalisis pengaruh norma subyektif, kinerja aparatur pemerintah, kejelasan sasaran anggaran dan prosocial behavior terhadapa transparansi dan akuntabilitas keuangan desa. Penelitian ini dilakukan pada desa di Kabuapten Lombok Timur. dan menggunakan tekhnik sampel purposive dan sampel yang digunakan 80 orang dan menggunakan regresi linier berganda. Hasil penelitian menunjukkan bahwa norma subyektif, kinerja aparatur pemerintah, dan kejelasan sasaran anggaran berpengaruh positif terhadap transparansi sedangkan prosocial behavior tidak berpengaruh terhadap transparansi. Sedangkan norma subyektif, kinerja aparatur pemerintah, dan kejelasan sasaran anggaran tidak berpengaruh terhadap akuntabilitas, sedangkan prosocial behavior berpengaruh positif terhadap akuntabilitas dan transparansi berpengaruh negatif terhadap akuntabilitas.
\end{abstract}

Kata Kunci: Norma Subyektif; Kinerja Aparatur; Kejelasan Anggaran; Prosocial Behavior; Transparansi.

\section{Effect of Subjective Norms, Apparatus Performance, Clarity of Budget Goals, Prosocial Behavior on Transparency and Accountability}

\begin{abstract}
This study aims to analyze the influence of subjective norms, performance of government officials, clarity of budget targets and prosocial behavior towards transparency and accountability of village finances. This research was conducted in a village in East Lombok District. and using purposive sample techniques and samples used by 80 people and using multiple linear regression. The results showed that subjective norms, the performance of government officials, and the clarity of budget targets had a positive effect on transparency while prosocial behavior had no effect on transparency. While subjective norms, performance of government officials, and clarity of budget targets do not affect accountability, while prosocial behavior has a positive effect on accountability and transparency has a negative effect on accountability.
\end{abstract}

Keywords: Subjective Norms; Apparatus Performance; Budget Clarity; Prosocial Behavior; Transparency.

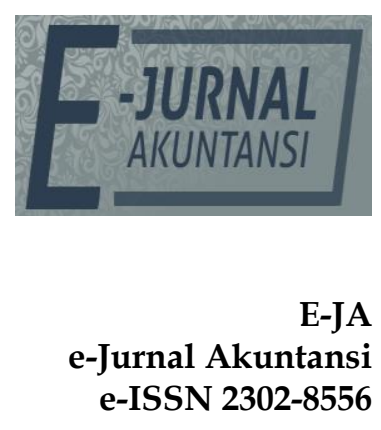

Vol. 30 No. 1

Denpasar, Januari 2020

Hal. 101-114

Artikel Masuk: 30 Agustus 2019

Tanggal Diterima: 9 Januari 2020 


\section{PENDAHULUAN}

Pada Undang-undang No. 6 Tentang Desa 2014 dijelaskan bahwa desa merupakan sebuah kesatuan masyarakat hukum yang memiliki batas-batas wilayah yang berwenang untuk mengatur dan mengurus kepentingan masyarakat setempat, berdasarkan asal-usul dan adat istiadat setempat yang diakui dan dihormati dalam sistem pemerintahan Negara Republik Indonesia. Untuk mengatur dan mengurus kepentingan masyarakat yang sejalan dengan pembangunan desa diperlukan pendapatan desa yang diatur dalam UndangUndang Desa sebagai Alokasi Dana Desa (ADD). Alokasi Dana Desa (ADD) merupakan bagian dari dana perimbangan yang diterima pemerintah daerah kabupaten/kota paling sedikit 10 persen setelah dikurangin Dana Alokasi Khusus (DAK).

Pada tahun 2018 saat menjelang pilkades serentak di Kabupaten Lombok Timur ada 45 persen desa yang dilibatkan tidak melakukan transparansi anggaran, padahal undang-undang tentang desa sudah dituntut setiap desa harus melakukan keterbukaan anggaran agar setiap masyarakat bisa mengetahui perkembangan dan juga program yang sudah dijalankan oleh pemerintah desa. Setelah pemilihan kepala desa serentak banyak masyarakat melakukan aksi atau unjuk rasa terkait dengan kinerja aparatur pemerintah desa yang buruk dan atas desakan masyarakat, kepala desa memberhentikan diantara aparatur pemerintah yang lama(Sekertaris Desa, 2019.)

Kinerja aparatur pemerintah desa merupakan suatu ukuran penilaian yang menyatakan seberapa jauh target (kuantitas, kualitas dan waktu) yang telah dicapai oleh pemerintah desa. Kinerja aparat pemerintah desa di Kabupaten Lombok Timur sering mendapat sorotan tajam dari masyarakat. Fenomena ini dapat dilihat dari rendahnya kemampuan serta keahlian aparat pemerintah desa dalam memberikan pelayanan yang baik. Kinerja aparatur pemerintah desa yang kurang bagus menunjukkan rendahnya pertanggungjawaban atau akuntabilitas setiap aktivitas aparatur pemerintah desa.

Akuntabilitas merupakan pertanggungjawaban pemerintah kepada masyarakat terkait dengan aktivitas-aktivitas dan kegiatan-kegiatan yang menjadi tangungjawabnya melalui penyajian laporan keuangan, dimana masyarakat mempunyai hak dan kewenangan untuk meminta pertanggungjawaban sebagai perwujudan transparansi pengelolaan pelaporan keuangan (Suratmi, 2014).

Transparansi keuangan desa merupakan salah satu bentuk sikap membuka diri dalam menyampikan informasi tentang keuangan desa yang jujur dan diskriminan. Agar transparansi pengelolaan pelaporan keuangan dapat cepat diakses oleh masyarakat maka pemerintah desa perlu membentuk normanorma yang baik terutama norma subyektif (Diolah Dari Permendagri No. 113/2014).

Menurut (Hanifah, 2015) norma subjektif terbentuk karena adanya keyakinan normatif dan motivasi dari pihak-pihak referen yang dipercayai oleh lingkungan kerja dan Penilaian terhadap norma subjektif dimaksudkan untuk mengetahui apakah lingkungan sosial mempengaruhi perilaku lingkungan kerja.(Praptoyo, 2015). 
(Dayaskini, 2006) membatasi perilaku prososial secara lebih rinci sebagai perilaku yang memiliki intens untuk mengubah keadaan fisik atau psikologis penerima bantuan dari kurang baik menjadi lebih baik, dalam arti secara material maupun psikologis. Dalam hal ini dapat dikatakan bahwa prososial behavior bertujuan untuk membantu meningkatkan well being orang lain, dikarenakan seseorang yang melakukan tindakan prososial turut mensejahterakan dan membahagiakan kehidupan orang. Beberapa peneliti menggunakan kerangka model theory of planned behavior untuk menjelaskan perilaku pemerintah desa dalam mengelola keuangan desa yang bersifat transfaransi dan akuntabel.

Penelitian (Lestari, 2015)menunjukkan bahwa pelaporan/ pertanggungjawaban anggaran dan aktivitas pengendalian berpengaruh terhadap akuntabilitas kinerja instansi pemerintah. Sama seperti Lestari menyajikan variabel indevenden kejelasan sasaran anggaran, sedangkan perbedaan penelitian ini adalah tidak ada aktivitas pengendalian dan juga penelitian ini menggunakan empat variabel indevenden yaitu norma subyektif, kinerja aparatur pemerintah desa, kejelasan sasaran anggaran, dan prosocial behavior sedangkan untuk variabel devenden transparansi dan akuntabilitas. Alasan peneliti untuk mengambil variabel ini adalah banyaknya pemerintah desa yang ada diKabupaten Lombok Timur dalam mengelola anggaran tidak banyak mencerminkan transparansi keuangan, sebab perilaku pemerintah desa masih kurang baik kaitanya dengan norma subyektif.

Penelitian Mahayani menemukan bahwa semua variabel independen berpengaruh terhadap variabel devenden disini variabel independenya yaitu Norma Subyektif, kinerja Aparatur Pemerintah, kejelasan sasaran anggaran Dan Prosocial Behavior sementara variabel dependen yaitu transparansi dan akuntabilitas. Kebaruan penelitian ini bahwa melihat sejauhmana perilaku pemerintah desa agar terwujudnya transparansi dan akuntabilitas keuangan dan sejauhmana terpenuhi kompetensi aparatur pemerintah desa dalam mengelola keuangan desa agar kejelasan sasarang anggaran. Berdasarkan praktik atau pengalaman kebijakan dana desa, maka perlu dicermati lebih lanjut penelitian pengaruh beberapa variabel terhadap pelaksanaan prinsip transparansi dan akuntabilitas diKabupaten Lombok Timur. Penelitian ini digunakan untuk mengetahui pandangan perangkat desa tentang trasnparansi dan akuntabilitas keuangan desa.

Dari uraian latar belakang maka ruusan masalah penelitian ini antara lain: 1. Apakah terdapat pengaruh norma subyektif terhadap transparansi keuangan desa? 2. Apakah terdapat pengaruh kinerja aparatur pemerintah desa terhadap transparansi keuangan desa? 3. Apakah Terdapat Pengaruh Kejelasan Sasaran Anggaran Terhadap Transparansi Keuangan Desa? 4. Apakah Terdapat Pengaruh Prosocial Behavior Terhadap Transparansi keuangan desa? 5. Apakah Terdapat Pengaruh Norma Subyektif Terhadap Akuntabilitas Keuangan Desa? 6. Apakah Terdapat Pengaruh Kinerja Aparatur Pemerintah Terhadap Akuntabilitas Keuangan Desa? 7. Apakah Terdapat Pengaruh Kejelasan Sasaran Anggaran Terhadap Akuntabilitas Keuangan Desa? 8. Apakah Terdapat Pengaruh Prosocial Behavior Terhadap akuntabilitas keuangan desa? 9. Apakah Terdapat Pengaruh Transparansi Terhadap akuntabilitas keuangan desa. 
Berdasarkan rumusan masalah diatas, maka tujuan penelitian ini adalah untuk menganalisis secara empiris pengaruh norma subyektif terhadap transparansi keuangan desa, pengaruh kinerja aparatur pemerintah desa terhadap transparansi keuangan desa, Pengaruh Kejelasan Sasaran Anggaran Terhadap Transparansi Keuangan, Pengaruh Prosocial Behavior Terhadap Transparansi keuangan desa, Pengaruh Norma Subyektif Terhadap Akuntabilitas Keuangan Desa, Pengaruh Kinerja Aparatur Pemerintah Terhadap Akuntabilitas Keuangan Desa, Pengaruh Kejelasan Sasaran Anggaran Terhadap Akuntabilitas Keuangan Desa, Pengaruh Prosocial Behavior Terhadap akuntabilitas keuangan desa, dan Pengaruh Transparansi Terhadap akuntabilitas keuangan desa.

\section{METODE PENELITIAN}

Penelitian ini merupakan penelitian asosiatif dengan pendekatan kuantitatif. Dalam hal ini peneliti menggunakan transparansi dan akuntabilitas, sebagai variabel dependen (variabel yang dipengaruhi), sedangkan norma subyektif, kinerja aparatur pemerintah desa, kejelasan sasaran anggaran, dan prosocial behavior sebagai variabel independen (variabel yang mempengaruhi).

Penelitian ini dilakukan pada seluruh desa yang ada di Kabupaten Lombok Timur yang mengelola keuangan desa yang meliputi kepala desa, sekrertaris desa, bendahara desa, dan badan permusyarawatan desa dalam pelaksanaan anggaran keuangan desa agar membentuk transparansi dan akuntabilitas.

Populasi adalah wilayah generalisasi yang terdiri atas obyek/subyek yang mempunyai kualitas dan karakteristik tertentu yang ditetapkan oleh peneliti untuk dipelajari dan kemudian ditarik kesimpulan(Sugiyono, 2016). Adapun yang menjadi populasi dalam penelitian berjumlah 255 desa yang ada di Kabupaten Lombok Timur yang berhubungan dengan perilaku pemerintah desa seperti kepala desa, sekretaris desa, aparat desa, dan badan permusyarawatan desa.

Sampel adalah bagian dari jumlah dan karakteristik yang dimiliki oleh populasi tersebut(Sugiyono, 2016) .Teknik pengambilan sampel dalam penelitian ini adalah non probability sampling yaitu purposive sampling. Purposive sampling adalah teknik penentuan sampel dengan pertimbangan tertentu(Sugiyono, 2016). Menurut (Sekaran, 2006) pengambilan sampel berdasarkan pertimbangan tertentu melibatkan pemilihan subyek yang berada di tempat yang menguntungkan atau dalam posisi terbaik untuk memberikan infansi yang diperlukan. Adapun jumlah sampel pada penelitian ini adalah 20 desa yang ada di Kabupaten Lombok Timur.

Kriteria sampel di penelitian ini kepala desa karena kepala desalah yang bertanggung jawab menyelenggarakan urusan pemerintahan, pembangunan dan kemasyarakatan. menjalankan tugas di samping berdasarkan kewenangan jabatan, juga berdasarkan kebijakan yang ditetapkan bersama antara Pemerintah Desa dan Badan Permusyawaratan Desa. Dalam pelaksanaan bidang administrasi dan surat menyurat yang baik bahwa sekertaris desa dimasukkan dalam penelitian ini. Untuk pelaksanaan perekapan dan memegang keuangan desa dan pelaksanaan anggaran bahwa bendahara desa dimasukkan dalam 
penelitian. Dan juga kaitanya dengan pengawasan anggaran dan perancang peraturan desa badan permusyarawatan desa dimasukkan dalam penelitian ini.

Tabel 1. Daftar Nama Desa Yang Menjadi Sampel Penelitian

\begin{tabular}{clc}
\hline No & Nama - Nama Desa & Responden \\
\hline 1 & Desa jerowaru & 4 Orang \\
2 & Desa setungkep & 4 Orang \\
3 & Desa Batu Belek & 4 Orang \\
4 & Desa Penedagandor & 4 Orang \\
5 & Desa Danger & 4 Orang \\
6 & Desa Montong Betook & 4 Orang \\
7 & Desa Api Taik & 4 Orang \\
8 & Desa Pringgasela Timur & 4 Orang \\
9 & Desa Lepak & 4 Orang \\
10 & Desa Rensing & 4 Orang \\
11 & Desa Sacra & 4 Orang \\
12 & Desa Sambelia & 4 Orang \\
13 & Desa Sekarteja & 4 Orang \\
14 & Desa Bilok Petung & 4 Orang \\
15 & Desa Sikur & 4 Orang \\
16 & Desa Suela & 4 Orang \\
17 & Desa Sukamulia & 4 Orang \\
18 & Desa Gapuk & 4 Orang \\
19 & Desa Terara & 4 Orang \\
20 & Desa Mamben & 4 Orang \\
\hline
\end{tabular}

Sumber: Badan Pusat Statistik, 2019

Alat analisis yang digunakan adalah regresi linear berganda dengan model persamaan sebagai berikut (Ghozali, 2016):

$$
\begin{aligned}
& Y 1=\alpha+\beta_{1} X_{1}+\beta_{2} X_{2}+\beta_{3} X_{3}+\beta_{4} X_{4}+\text { e........... } \\
& Y 2=\alpha+\beta_{1} X_{1}+\beta_{2} X_{2}+\beta_{3} X_{3}+\beta_{4} X_{4}+\beta_{5} X_{4}+e .
\end{aligned}
$$

Kerangan:

$$
\begin{array}{ll}
\mathrm{Y} 1 & =\text { Transparansi } \\
\mathrm{Y} 2 & =\text { Akuntabilitas } \\
\mathrm{a} & =\text { Konstanta } \\
\beta_{1}-\beta_{5} & =\text { Koefisien Regresi } \\
\mathrm{X}_{1} & =\text { Norma Subyektif } \\
\mathrm{X}_{2} & =\text { Kinerja Aparatur Pemerintah } \\
\mathrm{X}_{3} & =\text { Kejelasan Sasaran Anggaran } \\
\mathrm{X}_{4} & =\text { Prosocial Behavior } \\
\mathrm{e} & =\text { Standar Eror }
\end{array}
$$

\section{HASIL DAN PEMBAHASAN}

Penelitian ini terdiri 20 desa yang ada di Kabupaten Lombok Timur dengan jumlah responden 80 orang yang terdiri dari kepala desa, sekertaris desa, bendahara desa, dan badan permusyarawatan desa.

Dari 80 (100\%) kuesioner yang disebar, namun 73 kuesioner dikembalikan, atau $91,25 \%$ dan 70 kuesioner yang dapat diolah atau $87,5 \%$ dari total keseluruhan kuesioner telah disebar. 
Tabel 2. Tingkat Pengembalian Kuesioner Menurut Persentase ( \% )

\begin{tabular}{lcc}
\hline \multirow{2}{*}{ Keterangan } & \multicolumn{2}{c}{ Responden } \\
\cline { 2 - 3 } & Jumlah & Persen (\%) \\
\hline Kuesioner yang disebarkan & 80 & $100 \%$ \\
Kuesioner yang kembali & 73 & $91,25 \%$ \\
Kuesioner yang tidak dapat diolah & 3 & $3,75 \%$ \\
Kuesioner yang dapat diolah & 70 & $87,5 \%$ \\
\hline
\end{tabular}

Sumber: Data Penelitian, 2019

Hasil uji vaiditas pada penelitian ini menunjukkan bahwa nilai untuk $r_{\text {tabel }}$ sebesar 0,235. Nilai tersebut lebih kecil dari $r_{\text {hitung }}$ dari semua variabel dalam penelitian ini, artinya semua variabel dalam penelitian ini dikatakan valid.

Tabel 3. Hasil Uji Reliabilitas

\begin{tabular}{lcc}
\hline \multicolumn{1}{c}{ Variabel } & Cronbatch Alpha & Keterangan \\
\hline Norma subyektif & 0,748 & Reliabel \\
Kinerja aparatur pemerintah & 0,768 & Reliabel \\
Kejelasan sasaran anggaran & 0,718 & Reliabel \\
Prosocial behavior & 0,787 & Reliabel \\
Transparansi & 0,796 & Reliabel \\
Akuntabilitas & 0,609 & Reliabel \\
\hline
\end{tabular}

Sumber: Data Penelitian, 2019

Berdasarkan tabel 3 menujukkan bahwa semua variable pada penelitian ini memiliki nilai diatas dengan cronbatch alpa 0,60 artinya data pada penelitian ini dikatakan reliabel.

Nilai koefisien $\mathrm{R}^{2}$ bertujuan untuk mengetahui besarnya pengaruh variabel bebas secara bersama-sama terhadap variabel dependent atau untuk menunjukkan seberapa besar model regresi mampu menjelaskan variabelitas variabel dependent.

Tabel 4. Hasil Determinasi $\left(\mathbf{R}^{2}\right)$ Model 1

\begin{tabular}{|c|c|c|c|c|}
\hline del & $\mathrm{R}$ & R Square & Adjusted R Square & Error of the Estimate \\
\hline & $.675^{\mathrm{a}}$ & .455 & .422 & 2.875 \\
\hline
\end{tabular}

Sumber: Data Penelitian, 2019

Berdasarkan tabel 5 nilai koefisien determinasi menunjukkan bahwa nilai (Square ) adalah 0,455, atau 45,5\%. Bahwa norma subyektif, kinerja aparatur pemerintah desa, kejelasan sasaran anggaran, prosocial behavior, dan transparansi berpengaruh terhadap transparansi keuangan desa sebesar $24,7 \%$ dan sisanya dipengaruhi oleh variabel lain.

Tabel 5. Hasil Determinasi $\left(\mathbf{R}^{2}\right)$ Model 2

\begin{tabular}{|c|c|c|c|c|}
\hline del & $\mathrm{R}$ & R Square & Adjusted R Square & . Error of the Estimate \\
\hline & $.497 \mathrm{a}$ & .247 & .18 & 1.927 \\
\hline
\end{tabular}

Sumber: Data Penelitian, 2019

Berdasarkan tabel 5 nilai koefisien determinasi menunjukkan bahwa nilai (Square ) adalah 0,247, atau 24,7\%. Bahwa norma subyektif, kinerja aparatur pemerintah desa, kejelasan sasaran anggaran, prosocial behavior, dan transparansi berpengaruh terhadap akuntabilitas keuangan desa sebesar $24,7 \%$ dan sisanya dipengaruhi oleh variabel lain. 
Tabel 6. Hasil Uji Hipotesis Model 1

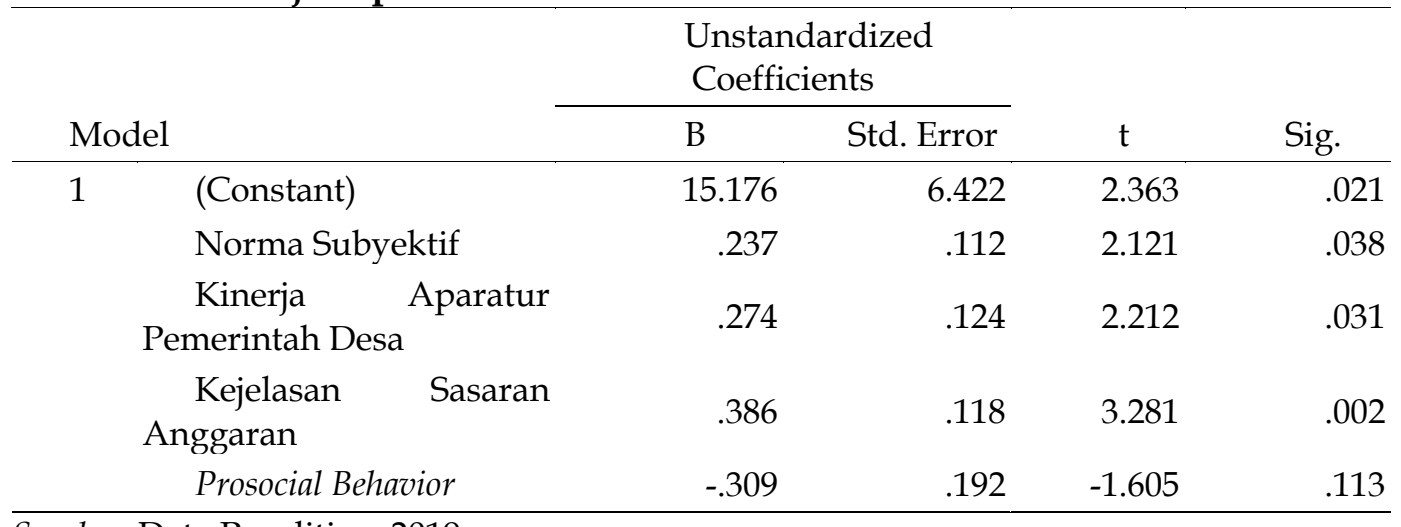

Sumber: Data Penelitian, 2019

Berdasarkan tabel 6 mengemukakan bahwa norma subyektif terdapat pengaruh positif signifikan terhadap transparansi di Kabupaten Lombok timur, dari hasil pengujian, menunjukkan bahwa hipotesis diterima, nilai $t$ hitung $>t$ tabel yaitu 2,121 > 1,997 dengan koefisien jalur 0,238 dengan arah positif, sedangkan nilai sig 0,038<0,05. Hasil uji membuktikan variabel X1 berpengaruh positif dan signifikan terhadap Y keuangan desa, artinya semakin baik tindakan pemerintah desa dalam pengelolaan keuangan semakin baik pula transparansi keuangan desa.

Hasil penelitian ini sejalan dengan theory of planned behavior sebagai perilaku yang ditimbulkan oleh individu muncul karena adanya niat - niat untuk berperilaku sebelum individu melakukan sesuatu, individu tersebut akan memiliki keyakinan mengenai hasil yang akan diperoleh dari perilakunya tersebut. Hasil penelitian ini juga sejalan dengan penelitian yang dilakukan (Nurofik, 2013).

Kinerja aparatur pemerintah desa memiiki pengaruh signifikan terhadap transparansi di Kabupaten Lombok timur, sesuai dengan pengujian menunjukkan bahwa hipotesis diterima dimana nilai $\mathrm{t}$ hitung $>\mathrm{t}$ tabel yaitu 2,212 $>$ 1,997 dengan koefisien jalur 0,236 dengan arah positif, sedangkan nilai sig 0,031 $>0,05$. Hasil uji ini membuktikan bahwa variabel kinerja aparatur pemerintah desa berpengaruh positif dan signifikan terhadap transparansi keuangan desa di Kabupaten Lombok timur. Artinya semakin bagus kinerja aparatur pemerintah desa akan menyebabkan transparansi keuangan desa semakin baik. Penelitian ini sejalan dengan(Amin, 2019) menunjukkan bahwa variabel kinerja aparatur pemerintah berpengaruh positif terhadap transparansi keuangan desa dan pengawasan BPD berpengaruh positif terhadap transparansi keuangan desa.

Kejelasan sasaran anggaran memiliki pengaruh signifikan terhadap transparansi di Kabupaten Lombok timur, dari pengujian, menunjukkan bahwa hipotesis diterima dimana nilai $\mathrm{t}$ hitung $>\mathrm{t}$ tabel yaitu 3,281 $>1,997$ dengan koefisien jalur 0,326 dengan arah positif, sedangkan nilai sig 0,002 >0,05. Hasil uji ini membuktikan kejelasan sasaran anggaran memiliki pengaruh positif signifikan terhadap transparansi keuangan desa di Kabupaten Lombok timur. Artinya semakin sesuai kejelasan sasaran anggaran akan menyebabkan transparansi keuangan desa semakin baik di Kabupaten Lombok Timur. Penelitian ini tidak sejalan dengan penelitian yang dilakukan (Lestari, 2015). 
Prosocial behavior tidak berpengaruh positif dan signifikan terhadap transparansi keuangan desa di Kabupaten Lombok timur, berdasarkan hasil pengujian dan analisis data, menunjukkan bahwa hipotesis ditolak dimana nilai t hitung lebih kecil dari nilai t tabel yaitu -1,605 lebih kecil dari 1,997 dengan koefisien jalur -0,149 dengan arah negatif, sedangkan nilai sig 0,113 lebih besar dari 0,05. Hasil uji ini membuktikan bahwa variabel prosocial behavior tidak berpengaruh positif dan signifikan terhadap transparansi keuangan desa di Kabupaten Lombok timur. Artinya prosocial behavior tidak memberi dampak terhadap transparansi keuangan desa di Kabupaten Lombok Timur. Keterbukaan anggaran yang dilakukan oleh pemerintah desa berdasarkan karena ada aturan dari pemerintah pusat dan daerah, bukan karena perilaku sosial pemerintah desa kepada masyarakat yang menjadikan transparansi keuangan desa, sehingga banyak pemerintah desa masih belum melakukan transparansi keuangan desa.

Theory of planned behavior menjelaskan bahwa ketika akan melakukan sesuatu, individu akan memiliki keyakinan tentang harafan normatif orang lain dan motivasi untuk memnuhi harapan tersebut, artinya perilaku sosial pemerintah desa tidak member dampak terhadap transparansi keuangan desa. Penelitian ini bertentangan dengan (Perdana, 2018).

Tabel 7. Hasil Uji Hipotesis Model 2

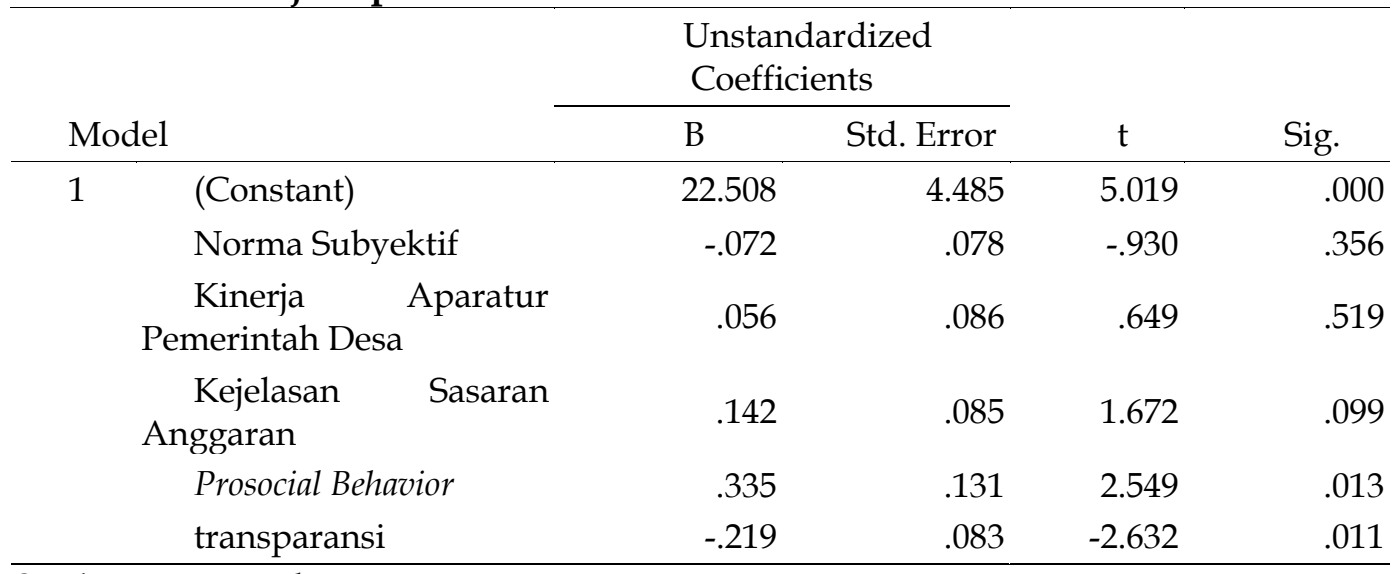

Sumber: Data Penelitian, 2019

Dari tabel 7 menunjukkan bahwa bahwa norma subyektif tidak memiliki pengaruh dan signifikan terhadap akuntabilitas di Kabupaten Lombok timur, berdasarkan hasil pengujian dan analisis data, menunjukkan bahwa hipotesis ditolak dimana nilai $t$ hitung $<\mathrm{t}$ tabel yaitu $-0,930<1,997$ dengan koefisien jalur 0,128 dengan arah negatif, sedangkan nilai sig 0,356 > 0,05. Mengemukakan Hasil uji ini membuktikan bahwa variabel norma subyektif tidak memiliki pengaruh terhadap akuntabilitas keuangan desa, artinya norma subyektif kaitanya dengan keyakinan dan motivasi untuk memenuhi sesuatu tidak member dampak terhadap akuntabilitas keuangan desa di Kabupaten Lombok Timur.

Menurut theory of planed behavior muncul niat berperilaku salah satu ditentukan oleh faktor control beliefs yaitu keyakinan individu tentang keberadaan hal - hal yang mendukung atau menghambat perilakunya dan persepsinta tentang seberapa kuat hal - hal tersebut mempengaruhi perilakunya. 
Kinerja aparatur pemerintah desa tidak memiliki pengaruh signifikan terhadap akuntabilitas di Kabupaten Lombok timur, berdasarkan hasil pengujian dan analisis data, menunjukkan bahwa hipotesis ditolak dimana nilai $\mathrm{t}$ hitung $<\mathrm{t}$ tabel yaitu 0,649 < 1,997 dengan koefisien jalur 0,085 dengan arah positif, sedangkan nilai sig 0,519>0,05. Hasil uji ini membuktikan bahwa variabel kinerja aparatur pemerintah desa tidak memiliki pengaruh positif terhadap akuntabilitas keuangan desa di Kabupaten Lombok Timur, artinya kinerja aparatur pemerintah desa tidak member dampak terhadap akuntabilitas keuangan desa. Sejalan dengan (Budi, 2017) menunjukkanbahwa Akuntabilitas, kemampuan kerja dan pengawasan secara bersama-sama berpengaruh secara signifikan terhadap kinerja aparatur desa se-Kecamatan Seririt.

Variabel kejelasan sasaran anggaran tidak memiliki pengaruh positif dan signifikan terhadap akuntabilitas keuangan desa di Kabupaten Lombok timur, berdasarkan hasil pengujian dan analisis data, menunjukkan bahwa hipotesis ditolak dimana nilai $\mathrm{t}$ hitung $<\mathrm{t}$ tabel yaitu 1,672 < 1,997 dengan koefisien jalur 0,236 dengan arah positif, sedangkan nilai sig 0,099 >0,05. Hasil uji ini membuktikan bahwa variabel kejelasan sasaran anggaran tidak berpengaruh positif dan signifikan terhadap akuntabilitas keuangan desa di Kabupaten Lombok timur. Penelitian ini sejalan dengan Penelitian (Suputra, 2018).

Prosocial behavior memiliki pengaruh signifikan terhadap akuntabilitas di Kabupaten Lombok timur, hasil dari nilai $t$ tabel yaitu 2,549 $>1,997$ dengan koefisien jalur 0,287 dengan arah positif, sedangkan nilai sig 0,013 $<0,05$. Hasil uji ini membuktikan bahwa variabel prosocial behavior berpengaruh positif dan signifikan terhadap akuntabilitas keuangan desa di Kabupaten Lombok timur. Artinya perilaku sosial pemerintah desa memberikan dampak terhadap terciptanya akuntabilitas keuangan desa di Kabupaten Lombok Timur. Penelitian ini sejalan dengan Penelitian (Mahayani, 2017).

Transparansi berpengaruh negatif dan signifikan terhadap akuntabilitas keuangan desa di Kabupaten Lombok timur, berdasarkan hasil pengujian dan analisis data, menunjukkan bahwa hipotesis ditrima dimana nilai $t$ hitung lebih besar tetapi memiliki nilai negatif dari nilai $t$ tabel yaitu $-2,632$ lebih besar dari 1,997 dengan koefisien jalur -0,387 dengan arah negatif, sedangkan nilai sig 0,011 lebih kecil dari 0,05. Hasil uji ini membuktikan bahwa variabel transparansi berpengaruh negatif dan signifikan terhadap akuntabilitas keuangan desa di Kabupaten Lombok timur. Artinya akses untuk mendapatkan informasi, dan keterbukaan anggaran pemerintah desa memberikan dampak negatif terhadap terciptanya akuntabilitas keuangan desa ini dikarenakan laporan anggaran dan pendapatan belanja desa (APBDes) banyak yang tidak sesuai dengan hasil musyawarah rencana pembangunan desa (MUSRENBANGDes), rencana kerja pemerintah desa (RKPDes) sampai ke APBDes sehingga antara keterbukaan anggaran dengan pertanggung jawaban mempunyai dampak negatif di Kabupaten Lombok Timur. Penelitian ini sejalan dengan Penelitian (Lestari, 2015). 
Tabel 8. Hasil Uji Kelayakan Model (Uji F) Model 1

\begin{tabular}{llrrrrr}
\hline \multicolumn{2}{l}{ Model } & \multicolumn{2}{c}{$\begin{array}{c}\text { Sum of } \\
\text { Squares }\end{array}$} & \multicolumn{1}{c}{ df } & \multicolumn{1}{c}{ Sean } \\
Square & \multicolumn{1}{c}{ F } & \multicolumn{1}{c}{ Sig. } \\
\hline \multirow{2}{*}{1} & Regressio & 449.064 & 4 & 112.266 & 13.582 & $.000^{\mathrm{a}}$ \\
& Residual & 537.279 & 65 & 8.266 & & \\
& Total & 986.343 & 69 & & & \\
\hline
\end{tabular}

Sumber: Data Penelitian, 2019

Dari tabel 8 menunjukkan bahwa nilai sig untuk hasil uji kelayakan model 1 sebesar 0,000 lebih kecil dari 0,05 artinya variabel independen norma subyektif,kinerja aparatur pemerintah, kejelasan sasaran anggaran, dan prosocial behavior mampu memperediksi variabel dependen transparansi. Begitu juga dengan nilai $\mathrm{f}$ hitung lebih besar dengan nilai $\mathrm{f}$ tabel 13,582 $>2,51$ artinya variabel independen mampu memperediksi variabel dependen.

Tabel 9. Hasil Uji Kelayakan Model (Uji F) Model 2

\begin{tabular}{|c|c|c|c|c|c|c|}
\hline Model & & $\begin{array}{l}\text { Sum of } \\
\text { Squares }\end{array}$ & $\mathrm{df}$ & $\begin{array}{l}\text { Mean } \\
\text { Square }\end{array}$ & $\mathrm{F}$ & Sig. \\
\hline \multirow[t]{3}{*}{1} & Regressio & 77.818 & 5 & 15.564 & 4.193 & $.002^{\mathrm{a}}$ \\
\hline & Residual & 237.554 & 64 & 3.712 & & \\
\hline & Total & 315.371 & 69 & & & \\
\hline
\end{tabular}

Sumber: Data Penelitian, 2019

Dari tabel 9 menunjukkan bahwa nilai sig untuk hasil uji kelayakan model 1 sebesar 0,002 lebih kecil dari 0,05 artinya variabel independen norma subyektif,kinerja aparatur pemerintah, kejelasan sasaran anggaran, prosocial behavior, dan transparansi mampu memperediksi variabel dependen akuntabilitas. Begitu juga dengan nilai $\mathrm{f}$ hitung lebih besar dengan nilai $\mathrm{f}$ tabel 4,193 > 2,36 artinya variabel independen mampu memperediksi variabel dependen.

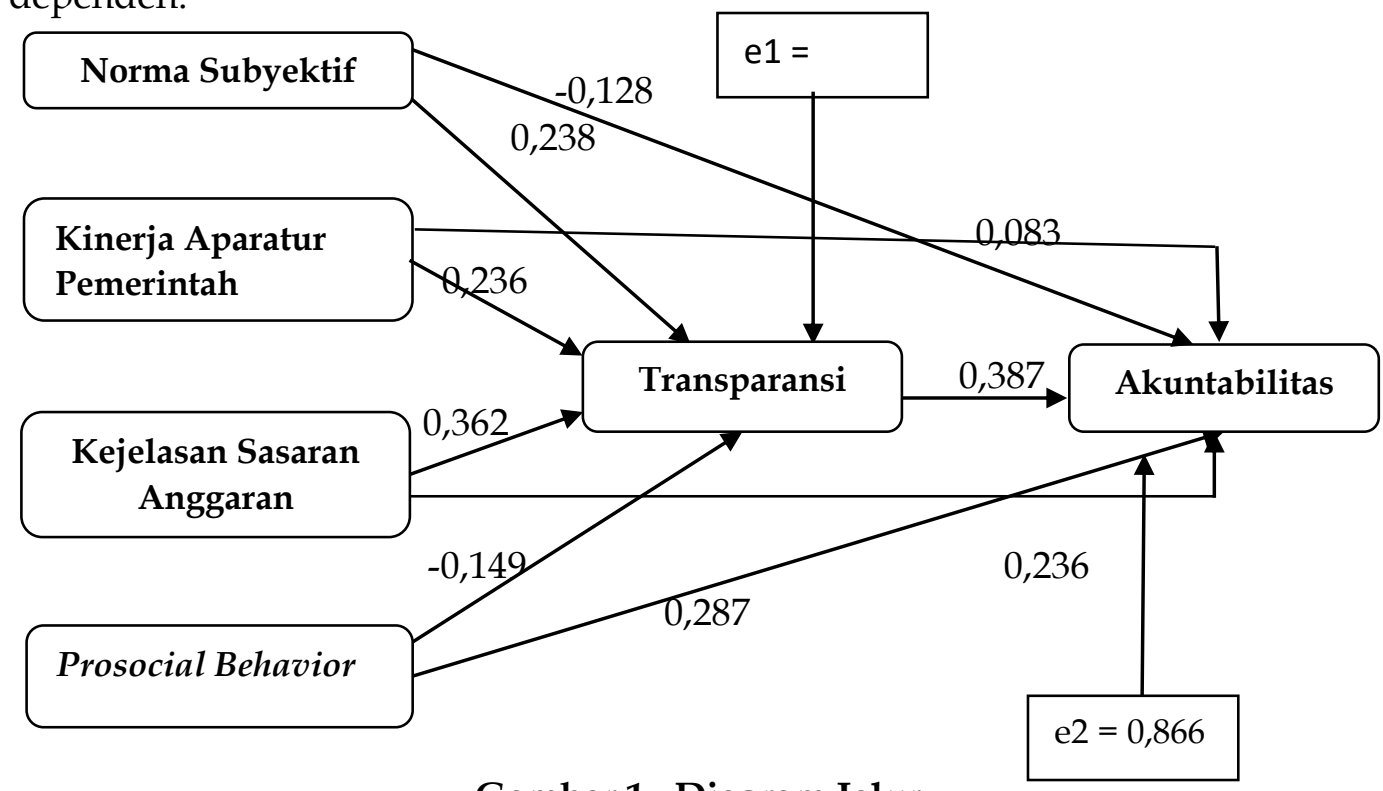

Sumber: Data Penelitian, 2019

Gambar 1. Diagram Jalur 
Besarnya pengaruh langsung norma subyektif terhadap transparansi sebesar 0,238. Besarnya pengaruh langsung kinerja aparatur pemerintah terhadap transparansi sebesar 0,236. Besarnya pengaruh langsung kejelasan sasaran anggaran terhadap transparansi sebesar 0,362 Besarnya pengaruh langsung prosocial behavior terhadap transparansi sebesar -0,149 Besarnya pengaruh langsung norma subyektif terhadap akuntabilitas sebesar -0,128. Besarnya pengaruh langsung kinerja aparatur pemerintah terhadap akuntabilitas sebesar 0,085. Besarnya pengaruh langsung kejelasan sasaran anggaran terhadap akuntabilitas sebesar 0,236. Besarnya pengaruh langsung prosocial behavior terhadap akuntabilitas sebesar 0,287 . Besarnya pengaruh tidak langsung norma subyektif terhadap akuntabilitas melalui transparansi $(0,238 \times-0,387)=-0,092$. Besarnya pengaruh tidak langsung kinerja aparatur pemerintah desa terhadap akuntabilitas melalui transparansi $(0,236 \times-0,387)=-0,091$. Besarnya pengaruh tidak langsung kejelasan sasaran anggaran terhadap akuntabilitas melalui transparansi $(0,362 \times-0,387)=0,140$. Besarnya pengaruh tidak langsung langsung prosocial behavior terhadap akuntabilitas melalui transparansi $(-0,149 \mathrm{x}-$ $0,387)=0,057$. Sedangkan Besarnya pengaruh total norma subyektif terhadap akuntabilitas melalui transparansi $-0,128+(0,238 \times-0,387)=-0,128-0,090=-$ 0218. Besarnya pengaruh total kinerja aparatur pemerintah terhadap akuntabilitas melalui transparansi $0,085+(0,236 \times-0,387)=0,085-0,091=-$ 0.006 .

Perilaku sosial pemerintah desa kepada masyarakat tidak memberikan dampak terhadapa terciptanya transparasni keuangan desa, padahal pemerintah pusata maupun daerah menuntutpemerintah desa selalu melakukan transparansi keuangan desa, pemerintah desa melakukan transparansi keuangan karena ada aturan pemerintah pusat dan daerah buan karena perilaku social peerintah desa. Sedangkan kinerja aparatur pemerintah desa, norma subyektif dan kejelasan sasaran anggaran memberikan dampak terhadapa terciptanya transparansi keuangan desa, semakin baik kinerja aparatur dan kejelasana sasaran anggaran akan semakin baik pula transparansi keuangan, akan tetapi ketiga variabel tersebut tidak memeberikan dampak pada pertanggunga jawaban keuangan desa, akuntabilitas keuangan desa berdampak pada perilaku sosial peerintah desa.

\section{SIMPULAN}

Dari uraian pada 20 desa, disimpulkan yaitu norma subyektif, kinerja aparatur pemerintah, dan kejelasan sasaran anggaran berpengaruh positif dan signifikan terhadap transparansi keuangan desa. Artinya sikap pemerintah desa juga mampu merubah keadaan didalam internal pemerintah desa kaitanya dengan pengelolaan keuangan pemerintah desa, sehingga transparansi keuangan desa harus dapat mudah diakses oleh masyarakat, karena banyak aparatur pemerintah desa ditemukan mengelapkan keuangan desa karena sikap dan karakter pemerintah desa sangat tidak baik sehingga apabila sikap dan karakter pemerintah desa sangat baik akan membentuk transparansi anggaran semakin baik pula. Hasil kerja yang dicapai oleh seorang aparatur pemerintah dalam melakukan suatu pekerjaan dapat dievaluasi tingkat kinerja, maka kinerja 
aparatur pemerintah harus dapat ditentukan dengan pencapaian target selama periode waktu yang dicapai sehingga apabila kinerja aparatur sangat akan menyebabkan transparansi semakin baik juga, begitu juga dengan kejelasan sasaran anggaran akan menyebabkan transparansi semakin baik juga, tidak dengan prosocial behavior berpengaruh negatif dan signifikan terhadap transparansi keuangan desa. norma subyektif, kinerja aparatur pemerintah, dan kejelasan sasaran anggaran dan transparansi tidak berpengaruh dan signifikan terhadap akuntabilitas keuangan desa. prosocial behavior berpengaruh positif dan signifikan terhadap akuntabilitas keuangan desa.

Dari hasil pengujian dapat ditarik kesimpulan bahwa. Pemerintah desa sebaiknya memeperhatikan norma - norma subyektif dan kinerja aparatur pemerintah dan kejelasan sasaran anggaran agar terbentuknya keterbukaan anggaran berdasarkan hasil penelitian bahwa ketiga variabel tersebut sangat mempengaruhi transparansi keuangan desa, dan juga untuk perilaku sosial pemerintah desa selalu memberikan manfaat kepada masyarakat sehingga transparansi keuangan bukan hanya sekedar aturan pemerintah pusat melainkan kesadaran pemerintah desa tersebut. Dan pada akuntabilitas keuangan desa tidak memberikan dampak apa - apa kepada ketiga variabel independen, sehingga saran peneliti agar meningkatkan norma subyektif, kinerja aparatur pemerintah dan kejelasan sasaran anggaran agar terciptanya akuntabilitas keuangan desa. Berdasarkan hasil penelitian ini bahwa ketiga variabel tersebut tidak berpengaruh pada akuntabilitas sedangkan perikau sosial pemerintah desa yang berpengaruh terhadap akuntabilitas keuangan desa.

\section{REFERENSI}

Ajzen, I. (2011). The theory of planned behaviour: Reactions and reflections. Psychology and Health. https:/ / doi.org/10.1080/08870446.2011.613995

Baldassarri, D., \& Grossman, G. (2013). The Effect of Group Attachment and Social Position on Prosocial Behavior. Evidence from Lab-in-the-Field Experiments. PLoS ONE, 8(3). ttps://doi.org/10.1371/journal.pone.0058750

Diansari, Rani Eka. (2015). Analisa Implementasi Alokasi Dana Desa (Add) Kasus Seluruh Desa Di Kecamatan Kledung Kabupaten Temanggung Tahun 2013. Seminar Nasional Universitas PGRI Yogyakarta, 1-11, 412-418.

Enggar, Sri Rahayu, dan W. (2011). Analisis Efisiensi dan Efektivitas Penerimaan Pajak Daerah Propinsi Jambi. Issn, 13(iv), 13.

Fitri Lestari. (2015). Pengaruh Kejelasan Sasaran Anggaran, Kinerja Manajerial, Pelaporan/Pertanggungjawaban Anggaran, Transparansi Publik dan Aktivitas Pengendalian Terhadap Akuntabilitas Kinerja Instansi Pemerintah ( Pada Pemerintah Kabupaten Lingga). Ekonomi, (8), 1-30.

Fitri Lestari. (2015). Pengaruh Kejelasan Sasaran Anggaran, Kinerja Manajerial, Pelaporan/Pertanggungjawaban Anggaran, Transparansi Publik dan Aktivitas Pengendalian Terhadap Akuntabilitas Kinerja Instansi Pemerintah ( Pada Pemerintah Kabupaten Lingga). Ekonomi, (8), 1-30.

Hanifah, S. I., \& Praptoyo, S. (2015). Akuntabilitas dan Transparansi Pertanggungjawaban Anggaran Pendapatan Belanja Desa (APBDes). Jurnal Ilmu \& Riset Akuntansi. 
Judarmita, I. N., \& Supadmi, N. L. (2017). Pengaruh Kejelasan Sasaran Anggaran, Sistem Pelaporan dan Audit Kinerja Terhadap Akuntabilitas Pengelolaan Dana Desa I. E-Jurnal Akuntansi Universitas Udayana.

Publik, P. A., \& Dan, K. K. (2017). Desa ( Studi Empiris Pada Desa Se-Kecamatan Seririt ). Made Budi Artini, 1(1).

Mahayani, N. L. A. (2017). Prosocial Behavior Dan Persepsi Akuntabilitas Pengelolaan Dana Desa Dalam Konteks Budaya Tri Hita Karana. Jurnal Ilmiah Akuntansi Dan Bisnis, 129.https:// doi.org/10.24843/jiab.2017.v12.i02.p07

M Amin. (2019). Pengaruh Kinerja Dan Pengawasan Aparatur Pemerintah Desa Terhadap Transparansi Keuangan Desa Montong Betok Kabupaten Lombok Timur. Jurnal Ilmu Pemerintahan Suara Khatulistiwa, Vol 4 No 2.

Nurofik, N. (2013). Pengaruh sikap, norma subyektif, dan kontrol perilaku pada pengungkapan tanggung jawab sosial. Jurnal Akuntansi \& Auditing Indonesia, 17(1), 43-56. https://doi.org/10.20885/jaai.vol17.iss1.art4

Pangastuti, T. N. (2013). Analisis Efisiensidan Efektivitas Penerimaan Pajak Daerah Kota Surakarta. Google Scholar, 12.

Perdana, A. A., Hasan, A., \& Rasuli, D. M. (2018). Pengaruh Sikap, Norma Subyektif, Persepsi Kontrol Perilaku dan Etika terhadap Whistleblowing Intention dan Perilaku Whistleblowing (Studi Empiris di BPKP Perwakilan Riau dan Sumatera Barat. Jurnal Akuntansi Keuangan Dan Bisnis, 11(1), 89-98.

Raharjo, T., Sjamsuddin, S., \& Hardjanto, I. (2013). Implementasi Kebijakan Alokasi Dana Desa (ADD ) Tahun 2011 Di Desa Jembul Dan Desa Sumengko Kecamatan Jatirejo Kabupaten Mojokerto Implementation of Village Fund Allocation Policy 2011 in Sumengko \& Jembul Village Jatirejo District, Mojokerto. 16(1), 32-40.

Respati, N. W. T. (2011). Pengaruh Locus Of Control Terhadap Hubungan Sikap Manajer, Norma-Norma Subyektif, Kendali Perilaku Persepsian, Dan Intensi Manajer Dalam Melakukan Kecurangan Penyajian Laporan Keuangan. Jurnal Akuntansi Dan Keuangan Indonesia. https://doi.org/10.21002/jaki.2011.08

Rofika, \& Ardianto. (2014). Pengaruh Penerapan Akuntabilitas Keuangan, Pemanfaatan Teknologi Informasi, Kompetensi Aparatur Pemerintah Daerah dan Ketaatan terhadap Peraturan Perundagan terhadap Akuntabilitas Kinerja Instansi Pemerintah. Jurnal Akuntansi, 2(2), 197-209.

Saeroji, A., Maskur, A., \& Tjahjaningsih, E. (2015). Pengaruh Norma Subjektif dan Kontrol Prilaku Yang Dipersepsikan Terhadap Niat Pinjam KUR Mikro ( Studi Pada Nasabah BRI di Pati). Kajian Multi Disiplin Ilmu Untuk Mewujudkan Poros Maritim Dalam Pembangunan Ekonomi Berbasis Kesejahteraan Rakyat, (i), 1-15.

Sugiyono. (2016). Metodologi Penelitian Kuantitatif, Kualitatif, dan RED. Bandung: CV Alfabeta.

Suratmi, N. M. (2014). Pengaruh Audit Kinerja, Penyajian Laporan Keuangan, Dan Aksesibilitas Laporan Keuangan Terhadap Akuntabilitas Publik. JIMAT (Jurnal Ilmiah Mahasiswa Akuntansi), 2(1). https://doi.org/10.23887/jimat.v2i1.2882

Telabah, I. W. S., Hermanto, H., \& Handajani, L. (2018). Implementation of Performance Accountability System For Government Institution (SAKIP) : 
Determinants and Consequence In Local Government. International Business $\begin{array}{llll}\text { and Accounting } & \text { Research }\end{array}$ https://doi.org/10.15294/ibarj.v2i2.36

Uma Sekaran. (2006). Metodologi Penelitian untuk Bisnis (4 buku 1). Jakarta: salemba empat.

Wicaksono, K. W. (2015). Akuntabilitas Organisasi Sektor Publik. JKAP (Jurnal $\begin{array}{llll}\text { Kebijakan Dan Administrasi Publik), } & 19(1), & \end{array}$ https://doi.org/10.22146/jkap.7523

Williams, N., P. Ferdinand, N., \& Croft, R. (2014). Project management maturity in the age of big data. International Journal of Managing Projects in Business. https://doi.org/10.1108/IJMPB-01-2014-0001 